\title{
LGBT dalam Perspektif Deotologi Immanuel Kant
}

\author{
Agus Hamzah ${ }^{1}$, Septiana Dwiputri Maharani ${ }^{2}$ \\ 1,2Program Studi Ilmu Filsafat, Universitas Gajah Mada, Yogyakarta, Indonesia \\ E-mail: agushamzah@mail.ugm.ac.id', septiana.dm@ugm.ac.id²
}

\begin{abstract}
Abstrak
Kasus LGBT yang semakin ramai menjadi bahan perbincangan di dunia dan juga Indonesia. Selain berbagai kelompok yang kontra, tidak sedikit pihak yang pro dengan memberikan berbagai argumentasinya. Satu diantaranya adalah dengan berlandaskan pada teori etika Immanuel Kant. Penelitian ini merupakan jenis penelitian kajian pustaka dengan menggunakan referensi teori yang relevan, yaitu teori Deontologi Immanuel Kant. Menurut perspektif Kant, dalam suatu perbuatan pasti ada konsekuensinya, dalam hal ini konsekuensi perbuatan tidak boleh menjadi pertimbangan. Perbuatan menjadi baik bukan dilihat dari hasilnya melainkan karena perbuatan tersebut wajib dilakukan. Tujuan yang baik tidak menjadi perbuatan itu juga baik. Dalam Teori Deontologi kewajiban itu tidak bisa ditawar lagi karena ini merupakan suatu keharusan. Berdasarkan analisis terhadap kajian kepustakaan tersebut didapat, bahwa Teori Deontologi meskipun dijadikan satu diantara landasan pembelaan terhadap LGBT dengan teori Hak, namun bahwa teori ini berlaku secara umum dan kondisi serta tempat yang sama, sehingga tidak sepenuhnya membenarkan keberadaan LGBT.
\end{abstract}

Kata Kunci: LGBT; deontology; kewajiban.

\begin{abstract}
LGBT cases are increasingly becoming a talking time in the world as well as Indonesia. In addition to the various groups that are cons, not a few parties are pros by giving various arguments. One of them is based on Immanuel Kant's ethical theory. This research is a type of library study study using the relevant theory reference, namely Immanuel Kant deontology theory. From Kant's perspective, in an act there must be consequences, in which case the consequences of the act should not be considered. Good deeds are not seen from the result but rather because they must be done. A good purpose is 1 not to be a good deed. In deontology theory of duty is no longer bargainable because it is a necessity. Based on the analysis of the literature study obtained, that the Theory of Deontology although used as one of the cornerstones of defense against LGBT with the theory of Rights, but that this theory applies in general and the same conditions and places, so as not to fully justify the existence of LGBT.
\end{abstract}

Keywords: LGBT; deontology; liability.

\section{Pendahuluan}

Pembahasan tentang lesbian, gay, biseksual, dan transgender atau biasa disingkat dengan sebutan LGBT, masih terus menjadi perdebatan di kalangan masyarakat dunia. Di Indonesia isu LGBT merupakan isu yang belum terselesaikan, karena masih tergolong hal yang tabu dan belum sepenuhnya dipahami oleh masyarakat Indonesia (Santoso, 2016: 221). Oleh karenanya, perilaku LGBT dianggap sebagai perbuatan yang memberikan gangguan keseimbangan, keselarasan, dan keserasian dalam masyarakat, serta menimbulkan kegaduhan dan ketakutan.

Isu mengenai LGBT saat ini sudah berada pada tatanan global, keberhasilan penyebarannya dicapai melalui serangkaian gerakan pro-LGBT yang telah ada sejak lama. Fenomena ini didukung dengan adanya deklarasi HAM universal (Universal Declaration of Human Rights) pada tahun 1948, serta reformasi politik dan demokratisasi yang sering "disalahpahami" sebagai proses liberalisasi dan kebebasan mengekspresikan diri. Secara keseluruhan, semakin makmur dan sekuler suatu bangsa, maka semakin besar 
kemungkinannya untuk merangkul hak-hak kaum LGBT. Sebaliknya, semakin miskin dan religius suatu bangsa, maka semakin besar kemungkinannya untuk menekan kaum LGBT. Terutama dari fakta bahwa negara itu demokratis atau tidak, meskipun hak LGBT tidak ditemukan di semua negara yang demokratis, hak LGBT hampir tidak ada dalam negara non-demokrasi (Encarnacion, 2014: 90-102).

Pemicu kembali maraknya isu LGBT di Indonesia juga disebabkan oleh keputusan Mahkamah Agung Amerika Serikat pada tanggal 26 Juni 2016 yang secara sah melegalkan pernikahan sesama jenis di 50 negara bagian Amerika Serikat atas dasar hak asasi manusia. Sebelumnya hanya terdapat 36 negara bagian yang melegalkan pernikahan sejenis di Amerika Serikat dan 14 negara bagian lainnya tidak setuju. Amerika Serikat menjadi Negara ke-21 yang melegalkan pernikahan sejenis (Sinyo, 2016: 43).

Berbagai lembaga survei independen dalam dan luar negeri menyebutkan bahwa di Indonesia kaum LGBT terdapat 3\% dari total jumlah penduduk. Maraknya fenomena LGBT di Indonesia sangat berkaitan erat dengan tren negara-negara liberal yang memberikan pengakuan dan tempat bagi komunitas LGBT di dalam masyarakat. LGBT dianggap sebagai bagian lifestyle masyarakat modern yang menganggap pandangan heteroseksualitas sebagai konservatis dan tidak berlaku bagi semua orang (Siregar, 1983: $6)$.

Menurut Hukum Pidana Islam, homoseksual termasuk dosa besar karena bertentangan dengan norma agama, norma susila, dan bertentangan pula dengan sunnatullah dan fitrah manusia. Agama Islam sendiri menganggap perilaku LGBT merupakan perbuatan yang termasuk dalam kategori dosa besar. Larangan untuk perilaku LGBT terdapat dalam sabda Rasulullah SAW yang diriwayatkan oleh at-Tirmidzi, al-Hakim, dan Ibnu Majah, "sesungguhnya yang amat ditakuti, paling aku takuti atas umatku ialah perbuatan kaum Nabi Luth" (HR at-Tirmidzi, al-Hakim, dan Ibnu Majah). Dari hadis tersebut, Islam telah dengan jelas melarang perilaku LGBT atau tindakan seksual sesama jenis. Hal ini juga tercantum dalam beberapa ayat Alquran tentang kaum Nabi Luth, salah satunya adalah Q.S. al-A'raaf [7]: 80-82. Dalam ayat itu, diceritakan bahwa Nabi Luth a.s. kedatangan tamu-tamu tampan, yakni malaikat yang menyerupai manusia. Kaum Nabi Luth (laki-laki) mengetahui hal tersebut dan berusaha untuk mendekati tamu-tamu Nabi Luth a.s. Namun, Nabi Luth a.s. melarang mereka dan bahkan menawarkan putri-putrinya untuk mereka nikahi. Mereka menolak tawaran Nabi Luth a.s., karena lebih tertarik dengan sesama jenis. Akibat dari perbuatan mereka, Allah memberikan azab kepada kaum Nabi Luth a.s. yaitu berupa hujan batu berapi dan kota mereka dijungkirbalikkan hingga benarbenar tidak ada yang tersisa. Islam menyebut tindakan seksual sesama jenis dengan liwath (Seran, 1999: 41).

Sedangkan menurut kelompok yang pro LGBT mengklaim bahwa memilih LGBT merupakan bagian dari hak asasi mereka. Oleh karena itu, mereka menuntut untuk dilindungi hak asasinya. Hak Asasi Manusia (HAM) merupakan hak dasar yang secara kodrati melekat pada diri manusia, bersifat universal dan langgeng, dan oleh karena itu, harus dilindungi, dihormati, dipertahankan, dan tak boleh diabaikan, dikurangi, atau dirampas oleh siapapun. Sedangkan dalam perspektif psikologi, dalam DSM III (Diagnostic and Statistic Manual of Mental Desorder), homoseksual dianggap sebagai salah satu kelainan jiwa atau kelainan seks, oleh karenanya LGBT dianggap sebagai perilaku yang tidak normal (Nicolosi, 2001: 71-72).

Perdebatan antara kelompok yang pro dengan kontra akan senantiasa menemui jalan buntu. Hal ini disebabkan oleh ketidakjelasan kelompok LGBT dalam hukum. Hukum nasional dalam arti luas tidak memberikan aturan secara tegas berkaitan dengan keberadaan kelompok LGBT. Beberapa kasus LGBT terjadi di Indonesia namun tidak ada hukum positif yang terlanggar secara pasti yang menyebutkan tindakan LGBT dan hanya mendekati perbuatan tersebut. Seperti yang tertera dalam pasal 292 KUHP yang berbunyi: "orang yang cukup umur, yang melakukan perbuatan cabul dengan orang lain sama kelamin, yang diketahui atau sepatutnya harus diduga, bahwa belum cukup umur, diancam dengan pidana penjara paling lama lima tahun".

Ketidakjelasan posisi LGBT dalam hukum, mengakibatkan sulitnya mengatasi persoalan yang terkait dengannya. Pengaruh dari arus LGBT pada akhirnya juga akan susah dibendung. Kelompok LGBT tentu akan semakin memiliki banyak pengikut.

Tidak adanya ketegasan hukum, maka tidak sedikit pelaku yang bebas dari jeratan pidana, karena hanya dianggap perbuatan pelecehan. Perbuatan LGBT juga dianggap sebagai penyakit yang menular. Perbuatan LGBT dapat merusak moral dan menentang 
nilai-nilai keseimbangan yang ada dalam moral masyarakat. Maka dari itu, kajian tentang LGBT perlu diseriuskan guna mendapatkan kejelasan dan landasan hukum bagi LGBT.

Etika, dalam hal ini sebagai salah satu peraturan yang menjadi dasar bagi tingkah laku masyarakat adalah satu di antara landasan yang tepat untuk mengupas tentang LGBT. Etika Immanuel Kant menjadi pisau analisis yang tepat guna memberikan pertimbangan-pertimbangan terkait masalah LGBT, karena dapat mengupas secara komprehensif, mulai dari tinjauan otonomi kehendak, kebaikan dan kebahagiaan, etika, dan agama.

Telah banyak artikel dan penelitian yang membahas tentang LGBT, dari sisi HAM, agama, psikologi, dan sosial. Namun belum ada yang meneliti tentang LGBT dalam perspektif etika, terutama etikanya Immanuel Kant. Oleh karena itu, penelitian ini orisinal dan berbeda dari penelitian yang lain.

\section{Metode Penelitian}

Penelitian di bidang filsafat sudah lama dijalankan, sejak fajar pemikiran filosofis oleh Sokrates, Plato, dan Aristoteles. Tetapi penelitian filsafat bisa berbentuk beragam-macam, dan kerap menampakkan diri seakan-akan hanya berupa pengarangan imajinasi atau berbentuk sastra belaka (Bakker, 1990: 5). Akan tetapi filsafat itu merupakan ilmu tersendiri, dengan objek formal khusus. Filsafat itu mencari suatu pemahaman kenyataan yang berbeda dari ilmu-ilmu lain. Maka perlu diberikan uraian teratur mengenai metodologi penelitian yang sesuai dengan objek formalnya (Bakker, 1990: 18).

Objek formal penelitian ini menggunakan pandangan etika, terutama etika deontologinya Immanuela Kant, dan objek materialnya adalah LGBT. Oleh karena itu, penelitian ini menggunakan metode kualitatif pustaka untuk menyelidiki pandangan etika terhadap eksistensi LGBT yang kemudian digunakan untuk merekonstruksi undang-undang pidana tentang LGBT di Indonesia.

a. Pengumpulan data

Peneliti mengumpulkan data pustaka dari berbagai perpustakaan, perorangan, dan sumber lain. Data primer akan diperoleh melalui data-data perkembangan LGBT di dunia, serta buku Etika Immanuel Kant. Sedangkan data sekunder diperoleh dari artikel-artikel atau penelitian yang telah lampau.

b. Pengolahan Data

Selanjutnya tahap pengolahan data, meliputi penerapan metode penelitian ilmiah untuk mengolah data yang tersedia dengan cara mengklasifikasikan data dalam sub-sub tema dan menyusunnya ke dalam bentuk konsep yang runtut dan utuh. Adapun langkah-langkah yang digunakan dalam pengolahan penelitian ini adalah sebagai berikut.

1) Reduksi data

Proses pengumpulan data berupa uraian verbal yang harus ditangkap maknanya. Data yang diperoleh ditulis atau diketik dalam bentuk uraian atau laporan yang terperinci.

2) Klasifikasi data

Data hasil dari reduksi dikelompokkan berdasarkan ciri khas masingmasing, sesuai kriteria dari masing-masing nilai yang terkandung.

3) Display data

Membuat berbagai macam pengklasifikasian sistematisasi atau network untuk melihat gambaran keseluruhan atau bagian-bagian tertentu dari penelitian ini.

c. Analisis data

Proses analisis data dilakukan pada saat, selama maupun setelah proses pengumpulan data. Berkaitan dengan akan adanya sejumlah besar data yang masih harus ditentukan hubungannya satu dengan yang lain, maka harus dilakukan klasifikasi data menurut jenis dan karakteristik sesuai dengan fokus penelitian.

Adapun unsur-unsur metodis yang dilaksanakan dalam menganalisis data, yaitu sebagai berikut.

1) Metode interpretasi (Soeroso, 2011: 11). Membaca dan memahami konsepsi LGBT dari sisi etika, yaitu konsepsi dasar mengenai manusia, masyarakat, dunia, dan Tuhan. 
2) Metode historis. LGBT tentu memiliki dimensi historis yang tidak dapat diabaikan. Pengungkapan dan penganalisisan dimensi historis tersebut, diperlukan metode historis.

3) Metode heuristik. Metode ini bertujuan untuk menemukan suatu jalan baru, pemecahan, serta inovasi pemikiran yang baru. Metode ini diperlukan untuk menganalisis dan menemukan pemikiran baru terkait undang-undang pidana bagi LGBT yang diterapkan pada data setelah pengumpulan data selesai dilakukan.

\section{Pembahasan}

\section{a. Penilaian LGBT di Indonesia}

LGBT atau pada zaman dahulu populer dengan sebutan homoseks telah ada sejak zaman Nabi Luth a.s. seperti yang tertera dalam Al-Qur'an Surah Al-A'raf ayat 8084. Negeri tempat tinggal Nabi Luth adalah Negeri Sadum, masyarakat negeri tersebut telah mengalami kehancuran moral yaitu lebih menyukai sesama jenis (laki-laki dengan laki-laki), sedangkan kaum perempuan tidak dipedulikan. Kaum LGBT tidak dapat dipungkiri eksistensinya, meskipun agama seperti Islam, Yahudi, dan Kristen secara tegas dalam setiap kitabnya mengutuk perbuatan homoseksual. Namun keberadaan mereka masih tetap ada walaupun secara sembunyi-sembunyi. Stigma negatif yang melekat pada perbuatan homoseksual menjadikan pelaku homoseksual melakukan aktivitas yang tertutup terutama yang berkaitan dengan perilaku seksual mereka.

Bulan Juni merupakan bulan yang spesial bagi komunitas LGBT (Lesbian, Gay, Biseksual, dan Transgender) di seluruh dunia. Setiap tahun pada bulan ini, komunitas LGBT di seluruh dunia melakukan selebrasi atas identitas mereka, atau yang dikenal dengan Pride Month. Selebrasi ini diadakan untuk meningkatkan kesadaran masyarakat akan keberadaan komunitas ini. Mereka berkumpul dan merayakan kebebasan untuk menjadi diri mereka sendiri. Ini berakar pada sejarah sulit dari kelompok-kelompok minoritas yang telah berjuang selama beberapa dekade untuk mengatasi stigma negatif dan supaya diterima sebagai diri mereka sendiri. Pemilihan bulan tersebut dimaksudkan untuk memberi penghormatan saat pemberontakan Stonewall pada Juni 1969 di New York City, AS. Aksi ini memicu gerakan hak-hak gay modern.

Hampir di semua belahan dunia, komunitas LGBT berkembang pesat, sejalan dengan pertentangan yang timbul karena keberadaannya. Di Indonesia, misalnya, arus penentangan terhadap LGBT terjadi lintas-agama, lintas-ideologi politik, dan bahkan lintas kelas sosial. Pergerakan gay dan lesbian di Indonesia adalah salah satu yang tertua dan terbesar di Asia Tenggara. Kegiatan Lambda Indonesia termasuk mengorganisir pertemuan sosial, peningkatan kesadaran, dan menciptakan buletin, tetapi kelompok ini dibubarkan pada tahun 1990-an. Gaya Nusantara adalah sebuah kelompok hak asasi gay yang berfokus pada isu-isu homoseksual seperti AIDS. Kelompok lain adalah Yayasan Srikandi Sejati, yang didirikan pada tahun 1998, fokus utama mereka adalah masalah kesehatan yang berkaitan dengan orang-orang transgender dan pekerjaan mereka termasuk memberikan konseling HIV/AIDS dan kondom gratis untuk transgender pekerja seks di sebuah klinik kesehatan gratis. Sekarang ada lebih dari tiga puluh kelompok LGBT di Indonesia (Erick, 2001: 40).

Diskriminasi eksplisit dan homofobia kekerasan dilakukan terutama oleh para ekstremis religius, sementara diskriminasi halus dan marginalisasi terjadi dalam kehidupan sehari-hari antara teman-teman dan keluarga di tempat kerja atau sekolah. Orang-orang LGBT sering mengalami pelecehan yang dilakukan oleh polisi tetapi sulit untuk mendokumentasikannya karena korban menolak untuk memberikan pernyataan seksualitas mereka. Orang-orang LGBT sering ditangkap atau dituduh karena orientasi seksual mereka. Di dalam penjara kaum gay juga mengalami pelecehan seksual karena orientasi seksual mereka, dan sering tidak melaporkannya karena telah menjadi trauma berupa takut dikirim kembali ke penjara dan mengalami kekerasan lebih lanjut. Majelis Ulama Indonesia memutuskan bahwa kaum transgender harus tetap pada jenis kelamin pada saat mereka dilahirkan. "Jika mereka tidak mau menyembuhkan diri secara medis dan agama," kata anggota Majelis, mereka harus rela "untuk menerima nasib mereka untuk ditertawakan dan dilecehkan" (Erick, 2001: 40). 
Lebih kurang lima persen atau kurang dari jumlah penduduk dewasa digolongkan sebagai biseksual aktif yang melakukan hubungan seksual sesama jenis pada tahun sebelumnya. Eccles dkk (2004: 11-18) dan Igartua dkk (2009: 602-608), menjelaskan identitas seksual sebagai persepsi individu tentang peran seksual dirinya yang dipengaruhi oleh kematangan individu.

Perilaku seksual diartikan sebagai suatu sikap dan tindakan untuk melakukan kontak seksual dengan orang lain (laki-laki, wanita, atau keduanya). Dalam pengertian ini, perilaku seksual merujuk pada aktivitas dan tindakan seksual dari seseorang. Sementara itu, American Psychological Association (2008) mendeskripsikan orientasi seksual sebagai sebuah kondisi emosional yang bertahan lama, romantis, dan daya pikat seksual untuk berhubungan dengan orang lain (laki-laki, wanita, atau keduany) (Ignartua, 2009: 602-608).

Kartini Kartono (2009), mengemukakan banyak teori yang menjelaskan sebabsebab homoseksual/lesbian, antara lain sebagai berikut.

1) Faktor herediter berupa ketidakseimbangan hormon-hormon seks. Faktor ini biasa juga disebut dengan teori "gay gene". Magnus Hischeld adalah ilmuwan pertama yang memperkenalkan teori ini pada tahun 1899. Dia menegaskan bahwa homoseksual adalah sifat bawaan sehingga dia menyerukan persamaan hukum untuk semua kaum homoseksual.

2) Namun teori ini kian runtuh ketika pada tahun 1999, Prof. George Rice dari Universitas Western Ontario Kanada, mengatakan tak ada kaitan gen $\mathrm{x}$ yang dikatakan mendasari homoseksual.

3) Pengaruh lingkungan yang tidak baik/tidak menguntungkan bagi perkembangan kematangan seksual yang normal.

4) Seseorang selalu mencari kepuasan relasi homoseks/lesbian, karena ia pernah menghayati pengalaman homoseksual/lesbian yang menggairahkan pada masa remaja. Salah satu contohnya: seorang anak laki-laki pernah mengalami pengalaman traumatis dengan ibunya, sehingga timbul kebencian/antipati terhadap ibunya dan semua wanita. Lalu muncullah dorongan homoseksual.

Kemudian terdapat beberapa faktor yang menyebabkan seseorang itu cenderung untuk menjadi bagian dari LGBT antara lain adalah:

1) Keluarga Pengalaman atau trauma pada masa anak-anak, misalnya: dikasari oleh ibu/ayah hingga si anak beranggapan semua pria/perempuan bersikap kasar dan bengis yang memungkinkan si anak merasa benci pada orang yang bersangkutan.

2) Pergaulan dan lingkungan menjadi faktor terbesar penyumbang kekacauan seksual ini. Seperti sikap anggota keluarga yang tidak menunjukkan kasih sayang, serta perasaan orang tua yang menganggap bahwa penjelasan tentang seks adalah suatu yang tabu.

3) Penelitian secara biologi telah dilakukan mengenai adanya keterkaitan antara genetika, ras, dengan hormon. Seorang homoseksual memiliki kecenderungan untuk melakukan homoseksual karena mendapat dorongan dari dalam tubuh yang sifatnya menurun/genetik.

4) Pengetahuan dan pemehaman mengenai agama yang lemah juga merupakan faktor internal yang mempengaruhi terjadinya homoseksual. Ini kerana peneliti merasakan didikan agama dan akhlak sangat penting dalam membentuk akal dan pribadi individu. (Kartini, 2009)

Faktor lingkungan yang berpengaruh terhadap perilaku reproduksi remaja di antaranya adalah faktor keluarga. Remaja yang melakukan hubungan seksual sebelum menikah banyak terjadi di antara keluarga yang bercerai atau pernah cerai, keluarga dengan banyak konflik dan perpecahan. Hubungan orang tua mempunyai pengaruh langsung dan tidak langsung dengan perilaku seksual pranikah remaja (Winarsih, 2013).

Faktor-faktor yang mempengaruhi perilaku seksual pranikah pada remaja paling tinggi adalah hubungan antara orang tua dengan remaja, tekanan teman sebaya, pemahaman tingkat agama (religiusitas), dan eksposur media pornografi. Di sisi lain, mereka juga bertemu dengan hal yang baru dalam kehidupan sosial kemasyarakatannya. Mereka sadar bukan lagi anak-anak, tetapi mereka juga belum mampu untuk mengekpresikan kemampuan dan potensi mereka dengan benar, karena orang-orang di sekitar mereka juga tidak menerima dan tidak mengakui mereka sebagai orang dewasa. Mereka mendapatkan sesuatu yang aneh dengan diri dan 
kehidupan mereka, tetapi mereka tidak dapat mengerti hal tersebut dengan pasti. Lebih jauh, ketika para remaja itu sendiri dan tidak ada orang yang membimbing dan membantu mereka, maka kemungkinan sesuatu akan terjadi pada mereka pada tahap perkembangan ini. hal itu bukan saja mengenai kendala dalam menemukan identitas diri mereka, tetapi juga mengenai orientasi seksualnya (Tucker, 2008: 387-389). Oleh karena itulah, banyak sekali penelitian yang telah dilakukan mencakup orientasi seksual yang terjadi di masa remaja serta identitas diri terkait dengan perkembangan LGBT. Penelitian ini pun akan memfokuskan pembahasan mengenai LGBT dalam pandangan deontologi Immanuel Kant.

\section{b. LGBT dalam Pandangan Deontologi}

\section{1) Etika Immanuel Kant}

Berbicara tentang penilaian berarti berbicara tentang baik dan buruk, bukan salah dan benar. Sesuatu yang baik bagi satu pihak belum tentu baik pula bagi pihak yang lain, begitupun sebaliknya. Sesuatu yang baik juga belum tentu benar, misalnya lukisan porno tentu bagus bagi setiap orang yang tidak mengingkarinya, kecuali mereka yang pura-pura dan sok bermoral, tapi itu tidak benar. Membantu pada dasarnya adalah baik tapi jika membantu orang dalam tindakan kejahatan adalah tidak benar.

Jadi, persoalan nilai adalah persoalan baik dan buruk. Penilaian itu sendiri timbul karena terdapat hubungan antara subjek dengan objek. Tidak ada sesuatu pun yang langsung mempunyai nilai dalam dirinya. Sesuatu itu baru mempunyai nilai setelah diberikan penilaian oleh seorang subjek kepada objek. Suatu barang tetap ada, sekalipun manusia tidak ada, atau tidak ada manusia yang melihatnya. "Bunga-bunga itu tetap ada, sekalipun tidak ada mata manusia yang memandangnya. Tetapi nilai itu tidak ada, kalau manusia tidak ada, atau manusia tidak melihatnya. Bunga-bunga itu tidak indah, kalau tidak ada pandangan manusia yang mengaguminya. Karena, nilai itu baru timbul ketika terjadi hubungan antara manusia sebagai subjek dan barang sebagai objek."

Aksiologi secara terminologis mempunyai arti yang bermacam-macam, karena para filsuf biasanya berbeda pendapat tentang masalah tersebut. Beberapa arti atau definisi terminologis untuk istilah aksiologi, antara lain adalah sebagai berikut.

a) Aksiologi adalah analisis atas nilai-nilai untuk menentukan makna, ciri, asal mula, corak, ukuran, dan kedudukan epistemologisnya (Mudhofir, 2001: 68).

b) Aksiologi merupakan analisis nilai-nilai, dalam arti membatasi arti, ciri-ciri, asal, tipe, kriteria, status epistemologis dari nilai-nilai tersebut.

c) Aksiologi adalah cabang filsafat yang berupaya menjawab persoalan "apa nilai itu" (Knight, 2007: 47)

d) Kattsoff (1989: 301) menyatakan istilah nilai memiliki beberapa makna sebagai berikut.

(1) Mengandung nilai (artinya berguna).

(2) Merupakan nilai (artinya baik atau benar atau indah).

(3) Mempunyai nilai (artinya, merupakan objek keinginan, mempunyai kualitas yang dapat menyebabkan orang mengambil sikap menyetujui atau mempunyai sifat nilai tertentu).

(4) Memberi nilai (artinya, menanggapi sesuatu sebagai hal yang diinginkan atau segala hal yang menggambarkan nilai tertentu)

Aksiologi merupakan kajian - dalam hal ini adalah cabang filsafat - yang berusaha mencari, menganalisis, atau menyelidiki hakikat nilai. Hakikat nilai dapat dicapai dengan mengungkapkan ciri, asal mula, corak, ukuran, dan kedudukan epistemologis dari nilai-nilai tersebut.

Nilai dapat dimaknai dalam berbagai macam sudut pandang. Nilai merupakan pemenuhan hasrat, kesenangan, minat, kesukaan, kehendak rasional murni, dan pemahaman atas sifat-sifat ketiga pengalaman sinoptik dari kesatuan pribadi, atau "hubungan benda-benda sebagai sarana untuk mencapai tujuan atau akibat yang ingin dicapai". Hakikat nilai menurut Mulyana (2004: 78) adalah rujukan dan keyakinan dalam menentukan pilihan, yang perwujudannya dapat berupa norma, etika, peraturan, adat kebiasaan, aturan agama, dan rujukan lainnya. Makna nilai yang hakiki adalah sesuatu yang diinginkan atau sesuatu yang tidak diinginkan.

Busro (1989: 1) menyatakan, hakikat nilai adalah dikotomis, dalam arti sifat yang positif dan negatif, berharga dan tidak berharga, berguna dan tidak berguna, baik dan 
tidak baik, benar dan salah, atau baik dan buruk. Nilai selalu bersifat ideal, sedangkan yang tampak hanyalah fakta, keberadaan nilai hanya dapat dirasakan atau dihayati.

Nilai dalam kehidupan manusia sangat kompleks dan tidak mudah dimengerti. Hal ini dikarenakan nilai melibatkan banyak komponen, mulai dari komponen psikologis, kepentingan, situasi, materi, dan sebagainya. Nilai dan penilaian dalam kehidupan sosial disandarkan pada dua hal, yaitu subjektivitas dan objektivitas. Meskipun demikian, penilaian dan pertimbangan kualitatif tentang situasi tertentu tidak hanya bersifat subjektif atau irasional. Penilaian dan pertimbangan menyangkut realitas dengan menantang berbagai pendapat serta cara kita melihat sesuatu. Oleh karena itu, sesuatu yang nyata bukan asas objektif yang apriori, melainkan sesuatu yang aposteriori. Realitas bukan sesuatu yang terselubung, melainkan sesuatu yang terlihat jelas dalam tugas komunikasi yang tidak pernah berakhir antara berbagai pribadi (intersubjektivitas) dengan lingkungan sosial maupun kebudayaan (Alfan, 2013:242).

Kehidupan memaksa untuk mengadakan pilihan, mengukur sesuatu dari segi baik atau buruk dan untuk memberi formulasi tentang ukuran nilai. Dalam kehidupan, sering dihadapkan pada persoalan yang menyenangkan atau tidak menyenangkan. Hal ini membuktikan bahwa setiap individu mempunyai perasaan tentang nilai. Apabila tidak melakukan pilihan, maka lingkungan yang akan menentukan pilihan. Persoalannya bukan harus atau tidak harus mempunyai ukuran, keyakinan, kesetiaan, atau idealisme untuk mengatur kehidupan, melainkan apakah ukuranukuran yang telah terbentuk itu dilaksanakan dengan konsisten atau tidak, dan apakah satuan atau sistem nilai itu dikembangkan dalam kehidupan atau dirusak? (Alfan, 2013: 252).

Teori nilai dalam filsafat mengacu pada permasalahan etika dan estetika. Etika memiliki dua arti, yaitu kumpulan pengetahuan mengenai penilaian terhadap perbuatan manusia; dan predikat yang dipakai untuk membedakan perbuatan, tingkah laku, atau yang lainnya. Nilai itu bersifat objektif, tapi kadang-kadang bersifat subjektif (Amsal, 2009). Dikatakan objektif jika nilai-nilai tidak tergantung pada subjek atau kesadaran yang menilai. Tolak ukur suatu gagasan berada pada objeknya, bukan pada subjek yang melakukan penilaian. Kebenaran tidak tergantung pada kebenaran pada pendapat individu melainkan pada objektivitas fakta. Sebaliknya, nilai menjadi subjektif, apabila subjek berperan dalam memberi penilaian; kesadaran manusia menjadi tolak ukur penilaian. Dengan demikian nilai subjektif selalu memperhatikan berbagai pandangan yang dimiliki akal budi manusia, seperti perasaan yang akan mengasah kepada suka atau tidak suka, senang atau tidak senang.

Menurut Kant, filsafat Yunani dibagi menjadi 3 bagian; logika, fisika, dan etika. Logika berkaitan dengan bentuk pemahaman dan rasio, fisika terkait persoalan hukum alam (law of nature), dan etika berkaitan dengan tindakan moral. Dalam etika ia mengembangkan model filsafat baru. Pemikiran ini dituangkan dalam karyanya, Critique of Pure Reason, yang berisi penjelasan tentang penyelidikan dan struktur keterbatasan akal itu sendiri. Dan dalam bukunya Critique of Practical Reason, yang berkonsentrasi pada penyelidikan etika, estetika, dan teologi (Russell, 1961: 67).

Etika, dalam pemikiran Kant sendiri dilatarbelakangi oleh realitas bahwa "rasio murni" (pure reason) yang menghasilkan sains tidak mampu memasuki wilayah objek noumena, yaitu dunia think in itself. Menurut Kant, rasio dan sains sangat terbatas dan hanya mengetahui penampakan objek fenomena. Ketika sains memasuki wilayah noumena, yang terjadi ia akan tersesat dan hilang dalam antinomi. Demikian pula jika rasio memasuki wilayah noumena, ia akan terjebak dan hilang dalam "paralogisme". Oleh karena itu, Kant berkeyakinan bahwa untuk memasuki wilayah noumena maka harus menggunakan "akal praktis" (practical reason). Dari sinilah pemikiran etika Kant muncul (Zubaedi, 2010: 68).

Terdapat tiga postulat kategoris dalam bangunan filsafat Kant, yang merupakan dalil-dalil akal praktis yang harus diterima dan dipercaya kebenarannya. Pertama, kebebasan (reiheit), yang dimaksud adalah kebebasan kehendak, sifatnya a priori dan transendental serta merupakan dasar kepribadian. Kedua, immortalitas (unsterblichkeit), yang dimaksud adalah immortalitas jiwa, berkaitan dengan summum bonum, yaitu kebaikan tertinggi (virtue atau highest good). Jiwa harus bersifat immortal agar dapat mencapai kebaikan tertinggi. Ketiga, eksistensi Tuhan (das 
dasein gottes), yang berarti Tuhan adalah kebaikan tertinggi, karena itu mempercayai adanya Tuhan adalah suatu keniscayaan. Dalam bukunya ia menyebutkan, "Tercapainya kebaikan tertinggi di dunia ini merupakan objek niscaya dari suatu kehendak yang dapat ditentukan oleh hukum moral. Dalam kehendak tersebut, kesesuaian secara menyeluruh keinginan dengan hukum moral merupakan kondisinya paling tinggi dari kebaikan tertinggi" (Kant, 1956: 202).

Dalam ruang lingkup filsafat etika, Kant termasuk pada filsafat etika aliran deontologi, yaitu suatu aliran filsafat yang menilai setiap perbuatan orang dan memandang bahwa kewajiban moral dapat diketahui dengan intuitif dan tidak memperhatikan konsep yang baik (Nainggolan, 1997: 68).

Karena faham deontologi yang dianutnya, maka Kant memandang bahwa perbuatan moral itu dapat diketahui dengan kata hati. Bagi Kant, melakukan kewajiban merupakan norma perbuatan baik. la mengambil contoh, perbudakan merupakan perbuatan buruk karena memakai manusia sebagai alat. Mempekerjakan pembantu rumah tangga dengan kasar merupakan perbuatan buruk pula, karena menjadikan manusia sebagai hewan (Nainggolan, 1997: 68).

Bagi Kant pula, hukum moral ini hanya berjalan sesuai dengan kata hati, dalam arti bahwa kata hati ini menjadi syarat kehidupan moral. Supaya moral ini baik, seseorang harus berbuat dengan rasa wajib (Encyclopedia Amerika, 1997: 251). Kant melihat bahwa, sebagaimana alam bisa berjalan dengan tertib, maka seperti itu pula dengan moral. Hukum moral harus berjalan secara tertib pula (Encyclopedia Amerika, 1997: 71).

Dalam konsepnya tentang moral yang dikaitkan dengan hukum alam ini, pada gilirannya Kant dapat menemukan Tuhan, dalam arti bahwa, seseorang dapat memiliki rasa mengenai ide fenomena ketuhanan, jika ia berusaha memikirkan hubungan Tuhan dengan dunia. Hal ini dapat dianalogikan dengan hubungan yang erat antara seorang ayah dengan anak-anaknya (Encyclopedia Amerika, 1997: 221).

Sebenarnya dari konsep inilah, lahirlah pemikirannya tentang perbuatan baik yang harus muncul sebagai kewajiban untuk berbuat baik sebagaimana layaknya seorang anak kepada bapaknya. Dalam kaitannnya dengan itu, Kant berpendapat bahwa hanya dengan menjaga keharmonisan hubungan alam (termasuk tingkah manusia) dengan Tuhan, maka dapat tercapai adanya kebahagiaan itu.

Dalam kaitannya dengan ilmu pengetahuan, Kant menekankan adanya kesucian hati sehingga dengan kesucian tadi, seseorang mampu memiliki intelegensia yang baik (Encyclopedia Amerika, 1997: 71). Oleh karena itu, kebahagiaan hidup seseorang dapat mencapai pengetahuan yang baik, dan memiliki perilaku yang utama hanya bisa didapat saat ia mampu menyatu dengan gejala alam yang secara kodrati telah diatur oleh Tuhan. Inilah makna dari kesucian hati itu. Dengan demikian, setiap orang, secara umum, sebenarnya mampu untuk membawa dirinya ke dalam lingkungan alamnya sendiri sehingga dapat menjumpai pandangan-pandangan moralnya yang dengannya ia sendiri dapat bekerja. Keyakinan inilah sebenarnya yang menjadi kunci dari filsafat moral Kant dan pandangan-pandangannya secara umum (Encyclopedia Amerika, 1997: 222).

Jika diambil suatu kecenderungan etika dan ilmu, kedua-duanya bergerak dalam tataran relatif. Karena sebuah ilmu yang tidak dilandasi etika, maka akan cenderung tidak terkontrol dan mengabaikan nilai-nilai moral. Jadi harus ada sinergi antara etika dengan ilmu. Memang untuk dapat menjadi ilmu, etika harus (antara lain) bersifat kritis, metodologis, dan sistematis. Kritis artinya setiap penerimaaan atau pernyataan harus mempunyai dasar yang cukup. Metodologis artinya dalam proses berpikir dan menyelidiki menggunakan suatu cara tertentu. Sistematis artinya bahwa pemikiran ilmiah dalam prosesnya dijiwai oleh suatu ide yang menyeluruh dan menyatukan sehingga pikiran-pikiran dan pendapat-pendapatnya tidak tanpa hubungan tetapi menjadi suatu kesepakatan (Makmurtono, 1989: 16).

\section{c. LGBT dalam Pandangan Etika Deontologi}

Sebagai contoh beberapa kasus LGBT di tanah air yang menjadi sorotan dunia, di antaranya adalah pesta gay di Kelapa Gading, hukum cambuk bagi pelaku gay di Aceh, pernikahan gay di Bali, dan pesta gay di Surabaya (dilansir dari liputan6.com). Memperlihatkan bahwa posisi LGBT di Indonesia terus mengalami perdebatan. Arus pro dan kontra terus berlawanan dengan mengemukakan pendapatnya masing-masing. 
Terlepas dari pro dan kontra yang terjadi di masyarakat, diskursus seputar LGBT sebenarnya mengerucut pada satu pertanyaan, "apakah perilaku LGBT merupakan perbuatan buruk/ salah?". Pertanyaan tentang status moral perbuatan homoseksual masuk dalam ranah filsafat moral atau etika normatif.

Satu-satunya argumentasi "favorit" pendukung LGBT adalah teori hak yang merupakan turunan dari teori Deontologi. Teori ini menjadi dasar lahirnya konsep Hak Asasi Manusia (HAM). Konsep HAM sendiri tidak bisa dilepaskan dari agama, karena dari manakah hak tersebut berasal jika bukan Tuhan yang menganugerahkannya kepada manusia? Dan secara umum, seluruh agama mengharamkan perilaku homoseksual, kecuali agamawan yang sudah berpandangan liberal. Teori HAM juga tidak tunggal, namun ada yang bersifat universal dan ada yang partikular, bergantung pada situasi dan kondisi negara masing-masing. Hak asasi menurut perspektif HAM bukanlah hak yang ansich, namun disertai dengan kewajiban atau tanggung jawab sosial.

"Deontologi" (Deontology) berasal dari kata dalam bahasa Yunani yaitu: deon yang artinya adalah kewajiban. Dalam suatu perbuatan pasti ada konsekuensinya, dalam hal ini konsekuensi perbuatan tidak boleh menjadi pertimbangan. Perbuatan menjadi baik bukan dilihat dari hasilnya melainkan karena perbuatan tersebut wajib dilakukan. Deontologi menekankan perbuatan tidak dihalalkan karena tujuannya. Tujuan yang baik tidak menjadi perbuatan itu juga baik. Di sini kita tidak boleh melakukan suatu perbuatan jahat agar sesuatu yang dihasilkan itu baik, karena dalam teori Deontologi kewajiban itu tidak bisa ditawar lagi karena ini merupakan suatu keharusan.

Kelompok LGBT menganggap apa yang dilakukannya adalah baik. Mereka pun berupaya menjadi warga negara yang baik, dengan menjalankan setiap kewajiban sebagai warga negara, seperti yang dilakukan masyarakat pada umumnya. Sejalan dengan itu, menurut etika deontologi, perilaku LGBT dinilai baik atau buruk berdasarkan pada tindakan yang sesuai atau tidak dengan kewajiban. Karena bagi etika deontologi, yang menjadi dasar baik buruknya perbuatan adalah kewajiban. Pendekatan deontologi sudah diterima dalam konteks agama, sekarang menjadi salah satu teori etika yang terpenting.

Ada tiga prinsip yang harus dipenuhi, yaitu sebagai berikut.

1) Supaya tindakan punya nilai moral, tindakan ini harus dijalankan berdasarkan kewajiban. Mengenai kelompok LGBT meninggalkan kewajibannya sebagai warga negara ataupun sebagai manusia, menjadi tolok ukur penilaian moral LGBT.

2) Nilai moral dari tindakan ini tidak tergantung pada tercapainya tujuan dari tindakan itu melainkan tergantung pada kemauan baik yang mendorong seseorang untuk melakukan tindakan itu, berarti kalaupun tujuan tidak tercapai, tindakan itu sudah dinilai baik. Upaya yang dilakukan kelompok LGBT dalam menjalani kehidupannya sebaik mungkin dianggap bernilai moral, meskipun tidak sesuai dengan kodratnya sebagai manusia.

3) Sebagai konsekuensi dari kedua prinsip ini, kewajiban adalah hal yang niscaya dari tindakan yang dilakukan berdasarkan sikap hormat pada hukum moral universal.

Dengan kata lain, tindakan LGBT dianggap baik karena tindakan itu memang baik pada dirinya sendiri, sehingga merupakan kewajiban yang harus dilakukan. Sebaliknya, jika tindakan LGBT dapat dinilai buruk secara moral maka tidak menjadi kewajiban untuk kita lakukan. Bersikap adil adalah tindakan yang baik, dan sudah menjadi kewajiban kita untuk bertindak demikian. Sebaliknya, pelanggaran terhadap hak orang lain atau mencurangi orang lain adalah tindakan yang buruk pada dirinya sendiri sehingga wajib dihindari.

Bagi Kant, hukum moral ini dianggap sebagai perintah tak bersyarat (imperatif kategoris), yang berarti hukum moral ini berlaku bagi semua orang pada segala situasi dan tempat. Perintah bersyarat adalah perintah yang dilaksanakan kalau orang menghendaki akibatnya, atau kalau akibat dari tindakan itu merupakan hal yang diinginkan dan dikehendaki oleh orang tersebut. Perintah bak bersyarat adalah perintah yang dilaksanakan begitu saja tanpa syarat apapun, yaitu tanpa mengharapkan akibatnya, atau tanpa memedulikan tercapai dan berguna bagi orang tersebut atau tidak. Artinya, jika dalam suatu negara LGBT dapat diakui sah dan dilindungi oleh hukum, maka tidak mustahil jika itu pula berlaku pada daerah atau negara lain.

Dengan demikian, etika deontologi sama sekali tidak mempersoalkan akibat dari tindakan LGBT, baik ataupun buruk. Akibat dari suatu tindakan tidak pernah diperhitungkan untuk menentukan kualitas moral suatu tindakan. Oleh karenanya hal ini 
membuka peluang bagi subjektivitas dari rasionalisasi yang menyebabkan ingkar akan kewajiban-kewajiban moral.

Perbuatan tidak pernah menjadi baik karena hasilnya baik, melainkan hanya karena wajib dilakukan. Karena itu, bisa dimengerti bahwa deontologi selalu menekankan bahwa perbuatan tidak dihalalkan karena tujuannya. Maka meskipun LGBT memiliki tujuan yang baik, namun cara yang ditempuh salah maka tetap tidak bisa dianggap baik.

Secara substansial, aliran ini berpandangan bahwa perilaku bermoral itu mesti melibatkan kesadaran diri pelaku, yakni menekankan sifat perilaku manusia. Manusia dikatakan melakukan sesuatu itu tidaklah semata-mata karena tindakan tersebut dipikirkan baik atau buruk, bukan pula karena adanya sesuatu dampak perbuatan tersebut, bukan pula perbuatan tersebut akan membawa dampak bagi sebanyak mungkin orang, tetapi kita melakukan perbuatan tersebut karena nilai perbuatan tersebut (Dierksmeier, 2013: 1-8). Jadi penentuan apakah LGBT dinilai baik, betul, wajar, dan bermoral sebagai sesuatu tindakan atau perbuatan itu jika ciri-ciri atau sifatnya sendiri. Sifat LGBT jika dilihat dari perspektif kesehatan, agama, dan psikologi, LGBT merugikan dan menyalahi aturan kodrat sebagai manusia, maka LGBT dapat dianggap perilaku yang tidak bermoral.

Dalam kaitan ini, ada beberapa bentuk teori deontologi, yakni: Deontologi tindakan, seperti eksistensialisme (etika situasi); dan deontologi peraturan, seperti prinsip kewajiban. Deontologi peraturan menyatakan bahwa pertimbangan moral diukur bergantung pada standard yang berlaku dan bukan karena kenikmatan (kesenangan) atau kesengsaraan. Tindakan yang sesuai dengan peraturan dianggap bermoral. Sementara deontologi tindakan berpendapat bahwa bermoral atau tidaknya suatu perilaku itu bergantung pada cara kita melaksanakan tanggungjawab pada orang lain. Adapun yang termasuk bagian dari deontologi tindakan adalah teori eksistensialisme.

\section{Simpulan}

Berdasarkan bentuk teori deontologi tersebut, dapat diketahui bahwa LGBT dapat dinilai baik jika dilihat dari deontologi tindakan. Kelompok LGBT meskipun dianggap tidak sesuai dengan norma yang berlaku (terutama di Indonesia), namun tidak melalaikan kewajibannya sebagai warga negara ataupun kewajiban sebagai manusia yang harus senantiasa berbuat baik. Namun secara deontologi peraturan, LGBT dianggap tidak bermoral, karena tidak sesuai dengan peraturan yang berlaku secara umum. Indonesia adalah satu di antara negara yang tidak mengesahkan prnikahan sejenis. Bahkan dalam posisi hukum, LGBT masih diberlakukan sama dengan masyarakat umum. Belum ada hukum yang secara khusus melindungi ataupun mengatur tentang mereka. Hal ini menggambarkan bahwa di Indonesia keberadaan LGBT belum diakui.

\section{Daftar Pustaka}

Ahmad tafsir, Dr., 1999, filsafat Umum: Akal dan Hati semenjak Thales sampai James: Pt. Remaja Rosyda Karya, cet.ke-7 Encyclopedia Americana, 1977

Alexander Seran, 1999, Moral Hukum, Jakarta: Obor.

Alfan, Muhammad. 2013. Pengantar Nilai Filsafat. Bandung: Pusaka Setia.

Amsal, B. 2009. Filsafat ilmu. Jakarta: Rajawali Pers.

Bismar Siregar, 1989, Bunga rampai karangan tersebar Bismar Siregar, Volume 2, Rajawali.

Busro, A., 1989, Nilai dan Berbagai Aspeknya dalam Hukum Suatu Pengantar Studi Filsafat Hukum, Jakarta: Penerbit Bharata.

Encarnacion, O.G. (2014). Gay Rights: Why Democracy Matters, Journal of Democracy, Vol. 25 (No. 3, July), pp. 90- 102.

Dierksmeier, Claus. 2013. "Kant on Virtue", Journal Business Ethics, April, p. 18.Encyclopedia Britannica, 1970

Joseph Nicolosi. 2001. The Removal of Homosexuality From The Psychiatric Manual, Catholic Social Science Review

Kattsoff, L., 1989, Element of Philosophy, Penerjemah Soejono Soemargono, Yogyakarta, Tiara Wacana.

Knight, G.R., 2007, Filsafat Pendidikan (Terjemahan Mahmud Arif), Jakarta: Penerbit Gama Media. 
Makmurtono, Agus dan Munawir. 1989. Etika (Filsafat Moral). Jakarta: Wira Sari.

Mudhofir, A., 2001, Kamus Istilah Filsafat dan IImu, Yogyakarta: Gadjah MAda University Press.

Mulyana, R., 2004, Mengartikulasikan Pendidikan Nilai, Bandung: CV. Alfabeta.

Nainggolan, Z.S, Dr. 1997, Pandangan Cendekiawan Muslim tentang Moral Pancasila, Moral Barat dan Moral Islam, Kalam Mulia: Jakarta.

Russell, Bertrand. 1961. History of Western Philosophy. London: George Allen \&amp; Unwin Ltd.

R. Soeroso, 2011, Pengantar Ilmu Hukum, Jakarta: Sinar Grafika

Sinyo, 2016. Loe Gue Butuh Tau LGBT.Depok: Gema Insani. 